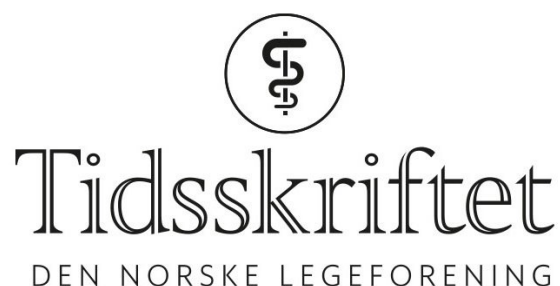

DEN NORSKE LEGEFORENING

\title{
Én felles reseptliste for pasienten
}

DEBATT

\section{LARS A. NESJE}

E-post: Inesje@online.no

Lars A. Nesje (f. 1956) er fastlege, kommuneoverlege og helsesjef i Salangen kommune.

Forfatter har fylt ut ICMJE-skjemaet og oppgir ingen interessekonflikter.

Pasienter har ofte flere forskjellige legemiddellister over faste legemidler. Det kan føre til feil som kan gi negative helsemessige følger. Det er på tide at vi får én felles elektronisk legemiddelliste.

E-resept har gjort formidling av informasjon om medikamentbruk mellom primær- og sekundærhelsetjeneste og pasienten både enklere og sikrere. Oversikten over legemidler i bruk (reseptformidleren) sammenfatter hvilke medikamenter en pasient bruker. Fastlegene er pålagt å ajourholde denne og samstemme den med epikriser fra sykehus og spesialister (forskrift om fastlegeordning i kommunene § 25). Fastlegene skal gjennomføre legemiddelgjennomgang når de finner det nødvendig.

Dersom en pasient gjennomgår innleggelser i flere sykehusavdelinger eller mottar behandling fra ulike spesialister, kan den manuelle samstemmingsoppgaven være omfattende og tidkrevende. Det er utviklet dataverktøy for å lette oppgaven, men den er fortsatt avhengig av gjentatt og oppmerksom bearbeiding fra fastlegen og at epikrise foreligger i rett tid.

Privatpraktiserende spesialister, sykehus, hjemmesykepleie og sykehjem har ikke systematisk og sikker tilgang til den ajourførte oversikten over legemidler i bruk eller kjennskap til om pasientens resepter fortsatt er gyldige for ekspedering fra apotek.

\section{Mange lister små...}

Se for deg følgende: En pasient som konsulterer legevaktlege legges inn på sykehus og skrives ut til pleietjeneste. I løpet av sykehusinnleggelsen blir pasientens medikamentelle behandling endret. Epikrise sendes etter hvert til fastlege som deretter forutsettes å oppdatere oversikten over pasientens legemidler i bruk i den elektroniske pasientjournalens e-reseptmodul. Deretter må fastlegen ta utskrift av listen og gi til hjemmesykepleien.

Hjemmesykepleietjenesten eller sykehjem kan ha fått informasjon fra sykehus før fastlegen mottar epikrise. Kanskje er det skrevet ut resepter fra sykehuset. Ifølge medisinsk fagsjef ved Universitetssykehuset Nord-Norge antas $80 \%$ av reseptene fra sykehuset å være skrevet som e- resept (Håkon Lindekleiv, personlig meddelelse).

Problemet er at det kan foreligge flere forskjellige oversikter over pasientens faste medisiner. Det brukes av flere årsaker mye arbeidstid til å forhindre feil i disse sårbare 
overgangene: For det første er det mulig for en behandlende lege på sykehus å forskrive resepter uten å redigere e-reseptoversikten over legemidler i bruk i reseptformidleren. For det andre har ikke sykehusleger og privatpraktiserende spesialister systematisk og sikker informasjon om pasientens faste medikamenter. For det tredje har ikke sykepleiertjenesten tilgang til Reseptformidleren og oversikt over legemidler i bruk eller reseptenes gyldighet. For det fjerde forutsetter multidosepakking papirbasert informasjon.

\section{Uutnyttet potensial}

E-resept og reseptformidleren har potensial for å bedre pasientsikkerheten uten ytterligere belastning på en allerede presset fastlegeordning. Det må da være en forpliktelse for alle inklusive sykehusleger og privatpraktiserende spesialister, som tar en klinisk beslutning om endring av pasienters faste medisiner, å registrere dette i reseptformidleren. Dermed vil det bare eksistere én legemiddelliste, og behovet for og risikoen ved samstemming bortfaller.

Forslag til løsning: Det skal bare eksistere én legemiddelliste. Dette bør være ereseptsoversikt over legemidler i bruk. Enhver forskrivning av medikamenter, inklusive multidose, skal skje via denne. Endring av pasientens faste medikamenter skal skje her. Dernest må oversikt over legemidler i bruk være tilgjengelig for de som gir nødvendig helsehjelp. Det betyr primært leger, men for pasienter som får bistand til legemiddelhåndtering innebærer det også tjenesteyter i hjemmesykepleie eller sykehjem.

Publisert: 22. januar 2018. Tidsskr Nor Legeforen. DOI:10.4045/tidsskr.17.1075

Mottatt 10.12.2017, første revisjon innsendt 14.12.2017, godkjent 15.12.2017.

(C) Tidsskrift for Den norske legeforening 2020. Lastet ned fra tidsskriftet.no 